Marinko Škare

Saša Stjepanović

UDK 330.101.52(497.5)

\title{
COMPUTABLE GENERAL EQUILIBRIUM MODEL FOR CROATIAN ECONOMY
}

\begin{abstract}
Computable General Equlibrium models or CGE models, are one of the most useful models in a global development planning and macroeconomic analysis. CGE models are discovered in 1960., but there was no major development until 1978. These models have become a standard tool of empirical economic analysis. These models dominate in major part of applied econometric analysis, which is involved on problem solving in economic development and local economic policies. They are inevitable tools for analysis in international trade and government planning, changes in oil markets, and at the same time they are used in the analysis in tax reforms, welfare distributions, and even in the analysis of global warming. From that it concludes that uses of CGE models are very wide-spread. In the last few years, improvements in a specification of the model, availability of data and development in computer technology results in increased efficiency and reduced cost of analysis, which is based on CGE models. CGE models are most commonly used for analysis in countries that are in transition, but basic framework and specification of a model can be used from global to the local level.
\end{abstract}

Keywords: CGE model, General equilibrium, Croatian Economy.

\section{THEORETICAL BACKGROUND OF CGE MODELS}

Computable General Equilibrium (CGE) models are simulations that combine the general equilibrium structure formalized with economic data to solve numerically for the levels of supply, demand and price that support equilibrium across a specified set of markets. CGE models are a standard tool of empirical analysis, and are widely used to analyze the aggregate welfare and distributional impacts of policies. They are in use in many different areas like fiscal reform, international trade, development planning, environmental regulation, etc. CGE models are based on circular flow of commodities in a closed economy, showed in Figure 1. In Figure 1. Households own the factors of production and are the final consumers of produced commodities, and Enterprises rent the factor of production from the household for producing goods and services that the household then consumes. Many of CGE models present government that has a direct impact on the economy, but in circular flow government have the more passive role to collect taxes and to distribute revenues in a form of transfer subsidies to the firms and households. There is the two trace in circular flow. One is supply of factor inputs (labor and capital services) that household provides to firms, for exchange in goods and services that households buy from firms. And another trace route in circular flow is the payments that households receives for supply of factor inputs to the firms, which are then spent on goods and services that are produced in firms.

Equilibrium in economic flows in Figure 1. results in protection of both products and value. Protection of products means that quantity of factors that household gives and commodities that are produce by the firms must be absorbed by the firms and household in the rest of the economy. Protection of value means that for the each activity in the economy the value 
of expenditure must be in balance with the value of income, and that each unit of expenditure must purchase some amount of some type of commodities. The implication of this is neither product or value can appear out of nowhere, nor can product or value disappears, which means every activity income must be balanced by other expenditure, and any transfer of purchasing power can only be effected through an opposing transfer of some positive amount of some produced good or primary factor service, and vice versa.

These accounting rules represent foundation of Walrasian General Equilibrium. Protection of product implies that firms' outputs are fully consumed by households, and that households primary factors are in turn fully employed by firms. Thus, for a given commodity the quantity produced must be equal to the sum of the quantities of that are demanded by the other firms and households in the economy. For a given factor the quantities demanded by firms must completely exhaust the aggregate supply endowed to the households. This is the familiar condition of market clearance.

Finally, the returns to households' endowments of primary factors, accrue to households as income that the households exhaust on goods purchases. The fact that households' factor endowments are fully employed, so that no amount of any factor is left idle, and that households exhaust their income, purchasing some amount of commodities---even for saving, reflects the principle of balanced budget accounting known as income balance.

The three conditions of market clearance, zero profit and income balance are employed by CGE models to solve simultaneously for the set of prices and the allocation of goods and factors that support general equilibrium. The three conditions define Walrasian General Equilibrium. Consequently, CGE models typically do not explicitly represent money as a commodity. However, in order to account for such trades the quantities of different commodities still need to be made comparable by denominating their values in some common unit of account. The flows are thus expressed in terms of the value of one commodity---the so-called numeraire good--whose price is taken as fixed. For this reason, CGE models only solve for relative prices.

\section{MACROECONOMIC TRENDS IN CROATIAN ECONOMY}

Croatian Economy, as well as all the transition economies during the period 1994. to 1998. performed under unstable international financial market conditions. Financial crisis from Asian markets spread to almost all emerging markets, causing increased uncertainty and investor confidence, which resulted in turning to the markets of developed countries.

The introduction of the single European currency is definitely an event that marked the end of the 1998th year. European Central Bank fixed euro exchange rate against the currencies of the Member States of the European Monetary Union and thus turned a new leaf in history. In January 1999. the financial crisis in Brazil has caused a sudden drop in the Brazilian currency, real, resulting in a significant increase in price of credits for emerging markets as it was, and the Croatian market. NATO action in Kosovo during the spring 1999th is reflected very negatively on tourism and traffic in Croatia. Croatia in 1999. year had privileged trade status with the European Union, because Croatia was not a member of CEFTA in that period and the export of Croatian products in the Central European transition countries was loaded uncompetitive tariffs.

In 2000 the negotiations were successfully completed, and Croatia joined the World Trade Organization, and also there have been concluded free trade agreements with Slovenia, Bosnia and Herzegovina and Hungary in February 2001. In October 2001 the Croatian candidature has been accepted for membership in CEFTA and signed the Agreement on Stabilization and 
Association Agreement, which improved relations between the Croatia and the EU. Strong slowdown in economic activity was marked by the world economy in 2001. year. Therefore, during 2002. the recovery of the world economy was still poor with uncertain prospects. Economic trends were then characterized with the war in Afghanistan and the uncertainty of the war in Iraq and the continued recession in Japan. In this environment of stagnation in the world economy, Croatia enters into the reforms, and in 2003. year comes to a significant slowing economy by all indicators of economic activity. External debt, balance of payments deficit and fiscal deficit marked the Croatian macroeconomic environment in 2003. year.

Economic situation in 2004 years marked the growth of economic activity, reducing the budget account deficit, a slowdown in external debt and maintaining price stability. In 2005 world economic growth reached $4.9 \%$. Despite the slowdown compared with the 2004 when it was $5.3 \%$, such growth is considered quite strong considering that the world is ruled by the trend of rising oil prices and the trend in monetary policy restrictions. The growth of world trade was also very high and amounted to $7.4 \%$ in 2005 in relation to the trade growth in 2006 of $8.5 \%$. The growth of the world economy in 2006 years was $5.2 \%$, an increase of $0.3 \%$ compared to the previous year. The main generators of growth in 2006 were strong personal consumption, investment and the positive contribution of net exports. In 2006 there was acceleration of real growth in personal consumption, which is the result of positive developments on the labor market.

The growth of the world economy in 2007 amounted to $5.0 \%$ slightly slowing down since the previous year. It also slows the growth of world trade that is $6.8 \%$ in 2007 . Reduction of economic activities that led to deceleration of growth are a consequence of higher prices of raw materials, turbulence in financial markets and the general deterioration in the international environment. The main generators of growth in 2007 were personal consumption and investments.

The Croatian economy is in the period from 1994 to 1998 achieved average annual growth of above $6 \%$. Such high real rates of growth were achieved in conditions of stable prices and exchange rate movements, growth in living standards and the significant growth of savings. Growth of gross domestic product (GDP) is considered one of the most important indicators of macroeconomic trends of each economy. After five years of consecutive growth in 1999 years there were a drop asset value of GDP from $-0.9 \%$.

After strong growth in personal and public consumption since 1994 to 1998 in 1999 a drop in personal spending of $3.0 \%$ and the fall in the share of consumption in the GDP by $2.3 \%$ was registered. Growth of investment has slowed and terminated in 1999 due to the reduction of public investments, reducing liquidity and default problems in the construction sector, but also reduced imports of capital goods in 1999 years of $6.6 \%$.

In 2000 there was a revival of economic activity, which resulted in the growth of gross domestic product of $3.8 \%$. Stronger economic activity in 2000 was supported by a stable macroeconomic environment expressed in the retention of price stability, exchange rate stability and a stable and liquid banking system. In addition, the restrictive fiscal policy has opened the possibility of conducting a more relaxed monetary policy as reflected recovery of monetary aggregates and total sales and intensified credit activity of the banking sector.

Stronger economic activity began in 2000 and continued in 2001 supported by macroeconomic stability. This was the highest growth rate since 1997 year with the lowest inflation since 1994 year. Growth was recorded virtually in all areas of the real economy. Continuing tight fiscal policy was reflected in the reduction of government spending and reduced budget deficit. This movement of fiscal policy and increased investment activity and private 
consumption was accompanied by significant growth of monetary aggregates and credit, and a fall in interest rates. Input trend of economic growth that began in 2001 continued in 2002. Subject is still a stable macroeconomic environment that was expressed in the retention price stability, exchange rate stability and a stable banking system.

In the 2004 GDP growth was 3.8\%, which is slowing from $0.5 \%$ with respect to 2003 . The growth of economic activity in 2004 resulted from the growth of net exports, private consumption and investment. Through 2005 and 2006 year GDP growth increases by $0.5 \%$ percentage points, while in 2007 year was 5.6\%. In addition the largest contribution to growth came from personal consumption and investment.

Unemployment since 1994 to 1998 increased pursuant to the demobilization of military forces, and restructuring of former socially-owned enterprises. The speed of absorption of the surplus labor force was dependent on private sector development, as well as foreign direct investments, which were at 1998 in Croatia at an extremely low level. After the 1998 the unemployment rate is constantly increasing until 2002 when it reaches a record unemployment rate in Croatia about 22.3\%. After the 2002 the unemployment rate was in slight decline, and 2007 year reached 14.8\% which is also the lowest unemployment rate in Croatia since 1995 year.

Average annual inflation in the period 1994 to 1999 was at 4\% annually. The exception was the year 1998 when the inflation rate amounted to $5.7 \%$ due to the introduction of value added tax. In 2000 inflation rates reached a highest value and stopped at $6.2 \%$. In the next period rate of inflation was around 3\% per annum. Largest increase of inflation rate matches with the rise in the price of crude oil and petroleum products, followed by the increase prices of product tobacco, which have significantly affected the rate of inflation.

The foreign trade of Croatia has a constant growth in balance of payments deficit, which is increasing from year to year with few year exceptions.

\section{BUILDING SAM FOR CROATIA}

Social accounting matrix (SAM) is a data framework that typically represents the economy of a nation. SAM is a square matrix in which each account is represented by a row and a column. Each cell shows the payment from the account of its column to the account of its row. For each account in the matrix total revenue (row total) equals total expenditure (column total). Social accounting matrix provides data for CGE models.

SAM (Social accounting matrix) is designed like generalized input - output table, and it provides a description of whole economy for the selected country. It has a form of a matrix where the number of rows is equal to the number of columns for each category of commodity, factor production and actors in the economy. Every row represents a source of origin for certain economic resources, which are connected with certain actor in the economy. Every column, opposite of rows, represents the way of use for those resources. Every actor in the economy and his behaviour must respect basic accounting principles of balance and that balance provides balance for social accounting matrix. These actors in the economy are represented by households, companies, government, etc. Exactly, these actors in the economy and their accounts describe in detail relationship between production structures and distributions of welfare, as well as financial transactions in a domestic economy, and later financial transactions with the rest of the world.

Thus, the SAM consists of a set of interrelated subsystems that, on the one hand, give an analytical picture of the studied economy in a particular accounting period and, on the other hand, serve as an instrument for assessing the effects of changes on the particular flows represented by it (injections and leakages in the system), which might be the result of policy measures. 
Therefore, the SAM can be seen as a working instrument for quantifying the flows in the economic circuit and for simulating the effects resulting from any changes in such flows. This session will not develop the latter aspect (the SAM modelling).

Table 1.

Aggregate SAM model for Croatia

\begin{tabular}{|c|c|c|c|c|c|c|c|}
\hline & Activity & Commodity & Household & Government & Investment & World & Total \\
\hline Activity & & $\begin{array}{c}\text { Domestic } \\
\text { sales }\end{array}$ & & & & Exports & Total Sales \\
\hline Commodity & & & $\begin{array}{c}\text { Household } \\
\text { consumption }\end{array}$ & $\begin{array}{l}\text { Government } \\
\text { consumption }\end{array}$ & Investment & & $\begin{array}{c}\text { Total } \\
\text { Apsorption }\end{array}$ \\
\hline Household & $\begin{array}{l}\text { GDP at } \\
\text { factor } \\
\text { cost }\end{array}$ & & & & & $\begin{array}{c}\text { Foreign } \\
\text { Remittances }\end{array}$ & $\begin{array}{l}\text { Household } \\
\text { Income }\end{array}$ \\
\hline Government & $\begin{array}{l}\text { Indirect } \\
\text { Taxes }\end{array}$ & Tariffs & Income Tax & & & & $\begin{array}{l}\text { Government } \\
\text { Revenue }\end{array}$ \\
\hline Savings & & & $\begin{array}{l}\text { Household } \\
\text { Savings }\end{array}$ & $\begin{array}{l}\text { Government } \\
\text { Savings }\end{array}$ & & $\begin{array}{l}\text { Foreign } \\
\text { Savings }\end{array}$ & $\begin{array}{c}\text { Total } \\
\text { Savings }\end{array}$ \\
\hline World & & Imports & & & & & $\begin{array}{c}\text { Total } \\
\text { Imports }\end{array}$ \\
\hline Total & $\begin{array}{c}\text { GDP } \\
\text { Market } \\
\text { Prices }\end{array}$ & Total Supply & $\begin{array}{c}\text { Total } \\
\text { Household } \\
\text { Expenditure }\end{array}$ & $\begin{array}{l}\text { Government } \\
\text { Expenditure }\end{array}$ & $\begin{array}{c}\text { Total } \\
\text { Investment }\end{array}$ & $\begin{array}{c}\text { Total } \\
\text { Foreign } \\
\text { Exchange }\end{array}$ & \\
\hline
\end{tabular}

Social accounting matrix for Croatia, we have calculated based on data from the Statistical Yearbook, and based on the authors own calculations. It is very important to emphasize that the matrix must be in balance as it is in accounting, matrix must fulfill the principle of balance, as well as in the social accounting matrix the total sum of each column must be equal to the total sum of each row. In order to achieve this so called systemic constraints are in use. Although in practice it is impossible to calculate some parts of the matrix in such a simple way, for the models limits are used such as, for instance: saving is equal to investment. Although in practice this is not absolutely true, for the needs of making the SAM this is taken as a necessary limitation that allows us to bring the matrix into balance, sum of each row must be equal to the sum of each column.

Table 1 presents a matrix of social accounting which will be used as a basis for further work with the CGE model. As it is seen, the matrix is composed of seven rows and seven columns with the same names, which are the following: Activity, Commodity, Household, Government, Investment, World and Total, which allow the equalization of columns with rows. 
Table 2.

Aggregate SAM model for Croatia for 2009

Table 2 shows the calculation of the SAM matrix for Croatia in 2009 year. It will be useful as the basis and foundation for the calculation of CGE model for Croatia. Most of the data was used from the Statistical Yearbook of the Central Bureau of Statistics. Data that are not found in the statistical yearbook are calculated by the author based on the system limitations of balance itself. These data are: foreign savings, government savings and foreign remittances.

CGE Model Framework for Croatian Economy

This Computable General Equilibrium model for Croatian economy will be built on Salter Swan framework, which gives excellent groundwork study how macroeconomic imbalance and policy adaptation effects on real sector in a small open economy.

CGE model with Salter Swan framework represents a respectable improvement against neoclassical models of exchange. These results are based on two assumptions. First assumption is that all goods and products in a model are tradable, and second one is that in a selected economy exists perfect substitutions between domestic and foreign goods. These two assumptions implicate method for determine prices for domestic goods and services on the world market.

The most important setting in Salter Swan framework is the differences between goods and services that are tradable and those that are not tradable. Non tradable goods and services are those which price is determined based on demand and supply on the domestic market. Price for goods and services that are tradable are determined on the world market. Fact that goods and services are non tradable may result from nature of goods and services (public goods or construction), or for example, there are very big transport costs for some good that there is no demand for that type of good, makes the good non tradable.

The standard Salter-Swan model is a two-sector, general equilibrium model that consists of three types of products: products that are not traded, export and import products. Country is assumed to have a small foreign trade, and therefore, faces a perfectly elastic supply from the rest of the world. In other words, it cannot affect the terms of trade and exchange of goods and services with the rest of the world. Institutional framework of Salter-Swan model of economy replicates the perfect competition with three principal participants in the market: 1) a producer who maximizes profit based on technical refinement and richness of the primary factors, 2) a consumer commodity that maximizes utility based on the overall budget constraints, and 3) the rest of the world. The balance is supposed to be a balance at the full employment level. Price factor and the product price is flexible enough to maintain the status of full employment.

The standard Salter-Swan model focuses on the effects of external shocks and the real exchange 
rate that ultimately affects the direct allocation of resources in the economy. The above assumptions describe the best of both worlds: perfect competition at home and free trade abroad. Given that the country is small, all goods that can be traded are aggregated in one well. Trade balance is exogenous variable in the model, while the homogeneity of factors, combined with price flexibility allows the free market. Finally, domestic and foreign products are perfectly interchangeable in consumption.

Salter-Swan basic model refers to one country with two production sectors and three products. This model is called "1-2-3 model". Two products that country produces are: (1) an export good, E, which are sold to foreigners, and it has no domestic demand, and (2) domestic product, D, which is sold on the domestic market. The third product is import, $\mathrm{M}$, which is not produced in the domestic market. In the model, there is only one consumer who receives all income. Country in the model is very small and has no impact on the world market, that meets with the fixed prices of imports and exports.

\section{MATHEMATICAL CHARACTERISTICS OF A GENERAL EQUILIBRIUM MODEL FOR CROATIA}

This model has three market participants: producers, households and the rest of the world. First equation defines the limit of domestic production capabilities, which gives the maximum possible combination of export goods and offers that can offer economies. The function is assumed to be concave and will be specified as constant elasticity of transformation (CET) function with elasticity of transformation. Constant in first equation define aggregate production, and it is fixed. Since the model does not have intermedia inputs, this equation is also equal to real GDP. Assume that fixed variable is equal to the assumption of full employment of all inputs of primary factors. Equation four shows the relationship between the effectiveness of domestic exports to output.

Equation one, defines the relationship between seven different prices. There are fixed world prices of exports and imports, domestic prices of exports and imports, prices of domestic products and prices of two composite products. Equation one and equation two are linearly homogeneous, and they correspond to double-pricing equations, nine and ten.

Equation two define composite products that create supply and demand for domestic products and imported goods consumed by a consumer. In multi sector models, this equation is used for multiple sectors, assuming that imports and domestic goods in the same sector are imperfect substitutes, and this version is called Armington assumption. Considering this assumption, it is considered that the composite product is expressed with a constant elasticity of a substitution (CES) aggregate function of imported and domestic products, the elasticity of substitution. 
Equation three is in a model instead for many complicated systems of equations of consumption, which is located in multi sector models and showing the important feature of all complete systems of consumption. The value of goods for which there is a demand must be equal to aggregate consumption. Equation three and five use zero level in prices, duplicated all prices, for example, offers a realistic level and the desired ratio of exports and imports remains unchanged. Since only relative prices are important, it is necessary to define a value (numeraire) price, which is determined in equation eleven, and it is the exchange rate.

Consumers maximize utility, which is equivalent to maximizing the composite product in this model, and then the equation five shows the desired ratio between the imported products and domestic products as a function of relative prices.

Equation six determines income households. Equation three defines household demand for composite product. Here it should be noted that all income is spent on a composite good. Prices:

Equation nine defines the composite price of the product, and it is a function of the cost taking into account the previous equation. Composite price of the product is equal to the GDP deflator.

The equation ten defines the cost of composite products. It is a function of costs with equation five. Price match aggregate consumer price index basket.

Equilibrium conditions:

Equations twelve, thirteen and fourteen define the market equilibrium conditions. Supply must be equal to the demand for goods and limitation in the balance of trade must be satisfied. The entire model has fourteen equations and thirteen endogenous variables. There are three conditions of equilibrium, but not the entire independent. Any of them can be dropped from the model, and pursuant to the model will be fully determined.

Identities: 
To prove that the three equilibrium conditions are not independent, it is enough to show that the model satisfies Walra's law. Such a model is closed in the way that no outside or outflows of funds exists in the economy. Identities that the model satisfies are shown in equations 15,16 and 17. The first two derive from the assumption of homogeneity, while the third stems from the fact that, in each system of equations of consumption, the value of purchase must be equal to the total consumption. When we multiply 12th equation and 13th with their respectable prices, the sum of equations 12 th 13 and 14 must be zero, as identity.

1-2-3 model is different from the standard neoclassical model of exchange in which all goods, tradable or not tradable, are perfectly replaced with domestic products. Empirical model that consists of these assumptions contains "one price law", which states that tradable domestic relative prices of goods, are determined based on world prices. This model tends to extreme specialization in production and unrealistic changes in domestic prices in response to changes in trade policies and world prices. Empirically is proven that the changes in the prices of imports and exports only partially affect the price level of domestic products. In addition, this (neoclassical) model can display two-way exchange in any sector, which is usually observed at higher level aggregation. This is why the 1-2-3 model is used, in which is stated imperfect substitution and transformation. In this case, all domestic manufactured products that are exported, are effectively treated like products, which are not traded. The share of these products in the GDP is now minus one share of exports, which is extremely large, and so all sectors are treated symmetric.

\section{CALIBRATION PROCEDURE, PROBLEMS AND CONSTRAINS TO USE CGE MODELS FOR SMALL OPEN ECONOMIES}

The design of a CGE model requires several steps. First, the structure of the general model is determined. Then, a particular functional form has to be chosen for the production and demand functions. Usually Cobb-Douglas, Linear Expenditure System (LES) or Constant Elasticity of Substitution (CES) specifications are selected for this purpose. Finally, the parameter values for the functional forms must be derived. Ideally, all the parameters in the CGE model may be econometrically estimated, using simultaneous equation estimation methods that take into account the overall model structure. However, given the size of CGE models, the required sophistication of techniques, the identification problems and the lack of data, this procedure is considered infeasible (Gunning and Keyzer, 1995). Therefore, the most commonly used procedure to determine the parameter values is calibration (Mansur and Whalley, 1984). The calibration procedure implies that the parameters of the model are identified based on a single observation of the economy. The economy under consideration is assumed to be in equilibrium, a so-called reference equilibrium or benchmark equilibrium. In practice, the benchmark equilibrium or benchmark data set is a Social Accounting Matrix, constructed from national accounts or other governmental data sources. The calibration procedure ensures that the parameters of the model are specified in such a way that the model will reproduce the initial data 
set as an equilibrium solution.

A very important characteristic of calibration is that the specification of the calibration model is not statistically tested because of the deterministic procedure by which the values do parameters from the database are derivated. That is why this approach uses a key assumption that the data from the databases represent a balance for economics that is being observed. For that a social accounting matrix is used, which is itself constructed in a way so that the data contained there are in equilibrium. The main advantage of the calibration model is the relative limitations of the data that are used in the model, or data do not need to be complete in order to construct a total model. These data can be used from a single observation, that was not the case with the econometric models. This characteristic is very important for countries in transition where there are very big limitations in data availability.

The main criticism of econometric models came from econometrics side among which are cited: the unreliability of data, the dependence of the quality of the model with the quality of data for the selected year and limited structure of the model. Unreliability of data is a very big problem with CGE models, especially because the value of the parameter is very important for later determination of the results at different simulations. The main problem here is that most data are derived from databases, although there are other data that are not in some databases, so they are being copied from some literature (most are data on the elasticity of substitution). However, the biggest problem is in those data that are not in any databases or literature. Therefore, these data are being affected based on some kind of assumptions. It is, in fact, the problem of unreliability of such data.

Another disadvantage is related to the quality of the data for the selected years, which directly affects on the quality of the whole model. In the econometric models, the stochastic distribution tries to reduce the errors in measurements of endogenous and exogenous variables in the model. However, in the calibration process assumption is the stochastic distribution is equal to zero, which then leads to that the calibration parameters must absorb all the mistakes that have been made in the data for the chosen base year. Furthermore, the social accounting matrix is not always in equilibrium, other words the sum total of the ranks is not equal to the total sum of the column, which also leads to some errors that occur in the process of bringing the matrix into balance.

Limitation of structure of the model as a third deficiency of calibration applies mainly on the functional form of the model. The main disadvantage is that the number of parameters, that are defined through the calibration, cannot be bigger than the number of equations in the model. To solve this problem, there are several solutions and one of these approaches is that parameter estimation must be based on data from more years and not a single base year.

In this section, the model is calibrated and the equilibrium model runs. Mathematical structure that is presented in the specification CGE model depends on several parameters (changes, distribution and elasticity), which must be specified so that the model numerically can be compatible with observations in the base year, which contains a matrix of social accounting. This is done in a calibration process where the values of structural parameters are expressed as a function of relevant variables in the model. When the values of the base year are used in the expression of function, and the model is solved using the values of the resulting parameters, the basic solution is being obtained.

Calibration and model initialization is done because the econometric estimation of parameters for individual equations for the whole model is usually impossible for two reasons. The first reason is the problem of identification of all the variables in the model, because the number of endogenous variables in the model is very large. Another problem of estimating 
parameters of the equation is that not all data are available for all equations. For example, for consumption, data on household budget may exist for some years, but certainly there are no aggregate time series' data. That is why in the development of CGE models the two options are in use, that allow solving the above problems. First is used an econometric evaluation components by component, which are observed independently of the production and consumption, and in use are data that are available from a variety of literature. Another solution is to set the other parameters that are not familiar through the calibration model, which is also called benchmarking method.

Calibration of the model is defined as a selection of numerical values of the parameters for the function of demand and supply function. Most often very important parameters, such as in our model the elasticity of export transformation (omega_x) and elasticity of substitution of the exchange of goods and products (sigma_q), are set as exogenous variables whose value is determined based on estimations (method that will be used in the model) or based on data that are calculated in different literatures. In our model, these two parameters will be estimated by the authors of the model based on data from earlier years.

\section{EVALUATING POSSIBLE EFFECTS OF THE WORLD CRISIS ON THE CROATIAN ECONOMY}

Below we show the possible movement of the value of certain variables in different scenarios. First scenario shows how the export price reductions of $10 \%$ have effect on all other indicators in the economy. Second scenario considers how it will affect the increase of price of exports from $10 \%$ to value for all other variables in the economy. Third scenario is showing the changes in variables induced by reducing tariffs by $10 \%$, while the fourth scenario shows the changes that will occur in economic variables in the case of any possible changes to increase tariffs by $10 \%$. Based on these selected scenarios we will show the movement and reactions of certain variables in the economic model on the possible external influences.

Table 3.

Household consumption

In the case of Scenario 1, the household consumption, as seen from the table above, total consumption of households falls in the amount of 9472 million, while in another scenario, the total consumption of households grows to 8093 million kuna. In the third and fourth scenario, there is a little change in total household expenditure in relation to the previous scenarios. In the case of reduction of tariffs by $10 \%$, leads to increase in total energy consumption of 115 million kuna, while in case of increasing tariffs by $10 \%$, leads to a reduction in total spending by 114 million kuna. From this we can conclude that the movement of household consumption shows a 
much greater sensitivity to changes in export rather than to changes in the amounts of custom duties.

Table 4.

\author{
Investments
}

The value of investments in the first scenario, falls for 553 million kuna, while in another scenario, in terms of increasing the value of exports, leads to growth in investments in the amount of 854 million kuna. In the third scenario where tariffs are reduced by $10 \%$, leads to a reduction of investments for 116 million kuna, while the fourth scenario, total investment grew for 114 million kuna. The total value of investments responds to external changes in a similar way as the movement of total household consumption by the individual scenarios.

Table 5.

$$
\text { Import }
$$

Trends in the value of imports in scenario 1 are in the direction of reducing for 7966 million kuna. In the next scenario, there is an increase in total imports for 7777 million kuna. In the third scenario, there is an increase in demand for imports by 8 million kuna, while in the fourth scenario, leads to a decrease in demand for imports by 9 million kuna. These small values and changes are surprising considering the large and direct dependence of import with the amount of import duties. 
Table 6.

\section{Domestic sale}

The value of domestic sales in the first scenario, falls in the amount of 1666 million kuna, while in the second scenario, there is an increase of domestic sales for the amount of 1531 million kuna. In the third scenario domestic sales is decreased for 9 million kuna, while in the fourth scenario, we have a decrease in domestic sales for 8 million kuna.

Table 7.

Saving

From Table 7 shown above, can be observed the movement of the variable saving through four listed scenarios. In the first scenario, there is a decrease of savings in the amount of 553 million kuna, while in the second scenario leads to increase of savings for 854 million kuna. In the next scenario, we have a case of reduce of saving in the amount of 116 million kuna, while in another scenario, saving is increased for 114 million kuna.

Table 8.

$$
\text { Export }
$$

Table 8 shows the movement of total exports considering to the observed scenarios and the changes in them. In the first scenario, is shown that in the case of reduction of price of exports 
leads to an increase in total exports for 1665 million kuna, while in case of the increase of price of exports by $10 \%$, we have a proportional reduction of total exports of 1531 million kuna. In scenario 3, exports is increased for 9 million kuna, while in the four scenarios exports fall for 9 million kuna. Here, can be emphasized that, although in the third and fourth scenario conditions change in tariffs, is amazing that total exports do not react to these changes and there is a very little change in total export.

Table 9.

\section{Household income}

Table 9 observe the movement of household income. Under the first scenario leads to reduced household income in the case of price reductions in the value of exports in the amount of 9840 million kuna. In the second scenario, there is an increase in household income due to increased export prices, which represents the result of theoretical thinking in the amount of 8407 million kuna. In the next two scenarios leads to minor changes in overall household income in the amounts of 119 and 120 million kuna. From this can be concluded that the decrease or increase in tariffs has a very little effect on total household income.

Table 10.

Goverment income

In the final table related to scenarios with different changes, we observe the movement of values of the total revenue of the state. In the first scenario, comes a decrease in state revenues in the amount of 5598 million kuna. In the next scenario leads to the growth of government revenue in the amount of 5415 million kuna. In scenario 3 comes to a reduction in state revenues in the amount of 166 million kuna. In the fourth scenario, there is an increase in state revenues in the amount of 164 million kuna.

As a conclusion the one fact is imposed, and that is that in the model all the variables range according to certain patterns of behavior that can be identified with theoretical postulates. The only variables that have different reactions to external stimuli are exports and imports who 
show little sensitivity to changes in the values of duty, although according to the theory, such as changes should be much higher.

\section{Conclusion}

CGE models are one type of tool that can be used for the assessment of external influences on the balance of the economy of a country. One of the advantages of these models is such that they can be successfully developed in those situations where there are no complete data or even no data at all. As Croatia is a young country, and its independence and autonomy is recently acquired, so the data available are not entirely complete with some period or for some period they even don't exist. So it is just a reason why we use CGE model, where with the process of calibration, we can avoid this disadvantage, and that does not violate the integrity of the model nor its quality. For now, there is no generally accepted macroeconomic model, which will give timely decisions as his result, which eased the external influences on the economy. Successful construction of the model of general equilibrium provides quality information and answers the question of how potential external influences can affect the Croatian economy. CGE models provide one of these responses were, based on data that are collected for one calendar year in which we included in the overall economy. We construct a balanced model, which show how external shocks, positive and negative, and changes affect the overall balance. Such models not only show how these influences throw the economy out of balance, but also give an answer how to take economy back into equilibrium, or how to reallocate resources within the economy in order to achieve equilibrium. The main goal of this paper is the very essence of CGE models, and that is that the model can provide answers to questions regarding the behavior of the economy in the future. Model itself is based on data in the present. However, based on these data can be given in response to changes that may occur afterward. The way the model works is to be brought into balance with the current data and then to identify the different scenarios that could happen afterward. The results of these scenarios, showing how the economy might react to changes and show changes in each variable separately. Based on these results later, we can take decisions that will in advance prepare the economy to external shocks.

Application of research results will provide understanding of how potential external shocks may affect the Croatian economy, which will provide high-quality information base for a possible reaction to the world economy crisis. Application of research results can be off in the further development of the CGE model, by spreading it to more sectors and adding more external and internal variables. The model in this range is a simplified representation of the economy, so it is very easy on the results of a simplified model to determine the direction of the development of the model and its expansion into new sectors and new variables that have not been added to the model, partly because of the simplicity of it due to statistical limitations. Using such a model proved to be very important for making decisions just for small transition countries that have not a significant impact on the world economy and so this model is well suited just for Croatia.

\section{BIBLIOGRAPHY}

1. James C. Moore, General Equilibrium And Welfare Economics, Springer, 2007.

2. Burkard Heer, Alfred MauBner, Dynamic General Equilibrium Modelling: Computational Metods and Applications, Springer, 2005.

3. Alessandro Citanna, John Donaldson, Herakles Polemarchakis, Paolo Siconolfi, Stephen E. Spear, Essays in Dynamic General Equilibrium Teory, Springer, 2005. 
4. H.Chenery, T. N. Srinivasen, Handbook of Develompent Economics vol.2, North-Holland, 1988.

5. Hans Lofgren, Rebecca Lee Harris, A Standard Computable General Equilibrium (CGE) Model in GAMS, International Food Policy Research Institute, 2002.

6. Christoper Dougherty, Introduction to Econometrics third edition, Oxford, 2007.

7. Badi H. Baltagi, Econometrics fourth edition, Springer, 2008.

8. Damodar N. Gujarati, Basic Econometrics fourth edition, The McGraw-Hill Companies, 2004.

9. Fumio Hayashi, Econometrics, Princenton University Press, 2000.

10. A. H. Studenmud, Using Econometrics and Eviews Software Package, Addison Wesley, 2001.

11. William E. Griffits, R. Carter Hill, Guay C. Lim, Using Eviews for Principles of Econometrics, Wiley, 2008.

12. George G. Judge, William E. Griffits, R. Carter Hill, Undergraduate Econometrics, Using Eviews For, Wiley, 2000.

13. Dimitrios Asteriou, Stephen G. Hall, Applied Econometrics, Palgrave Macmillan, 2007.

14. Ross M. Starr, General Equilibrium Theory, Cambridge University Press, 2001.

15. Michael Wickens, Macroeconomic Theory: A Dynamic General Equilibrium Approach, Princeton University Press, 2008.

16. Eurostat, MMF, World Bank, UN, OECD, Sustav Nacionalnih Računa 1993, Državni Zavod za Statistiku, 1993.

17. Donald Brown, Felix Kubler, Computational Aspects of General Equilibrium Theory, Springer, 2008.

18. Doina Maria Radulescu, CGE Models and Capital Income Tax Reforms, Springer, 2007.

19. Shantayanan Devarajan, Delfin S. Go, Jeffrey D. Lewis, Sherman Robinson and Pekka Sinko, Simple General Equilibrium Modeling, Cambridge University Press, 1997.

20. R. R. Johanson, A Guide to Using Eviews with Using Econometrics: A Practical guide, University of San Diego, 2000.

21. Ozge Senay, Disinflation Dynamics in an Open Economy General Equilibrium Model, University of York, 1999.

22. Sergey Paltsev, Moving from Static to Dynamic General Equilibrium Economic Models, MIT Press, 2004.

23. Ian Sue Wing, Computable General Equilibrium Models and Their Use in Economy-Wide Policy Analysis, MIT Press, 2004.

24. Benjamin H. Mitra-Kahn, Debunking the Myths of Computable General Equilibrium Models, City University, 2008.

25. Andrea Moro, Peter Norman, A General Equilibrium Model of Statistical Discrimination, University of Minnesota, 2002.

26. Channing Arndt, Sherman Robinson, Finn Trap, Parameter Estimation for Computable General Equilibrium Model: A Maximum Entropy Approach, International Food Policy Research Institute, 2001.

27. Frank Smets, Raf Wouters, An Estimated Stohastic Dynamic General Equilibrium Model of the Euro Area, European Central Bank, 2002.

28. B. Essama-Nssah, Building an Applied General Equilibrium Model, The World Bank, 2006.

29. B. Essama-Nssah, Intorduction to the Syntax of the Eviews, The World Bank, 2006.

30. Minnesota Implan Group, Elements of the Social Accounting Matrix, IMPLAN group, 2002.

31. Benjamin S. King, What is SAM? A Layman's guide to social accounting matrices, The World Bank, 1981. 
32. Susana Santos, Social Accounting Matrix and the System of National Accounts: An Application, Technical University of Lisbon, 2005.

33. B. Essama-Nessah, Building and Running General Equillibrium Models in Eviews, The World Bank, 2004.

34. http://www.dzs.hr

35. http://epp.eurostat.ec.europa.eu

36. http://www.worldbank.org/

37.http://ec.europa.eu/economy_finance/indicators/annual_macro_economic_database/ameco_en. htm

38. http://unstats.un.org/unsd/sna1993/tocLev8.asp?L1=20\&L2=3

\section{MODEL OPĆE RAVNOTEŽE REPUBLIKE HRVATSKE}

\section{Sažetak}

Computable General Equilibrium modeli ili CGE modeli, odnosno modeli opće ravnoteže su jedni od najkorištenijih modela u globalnom razvojnom planiranju i makroekonomskoj analizi. CGE modeli su otkriveni 1960. godine, međutim do njihovog većeg razvoja došlo je tek nakon 1978. godine. Ti modeli dominiraju u velikom dijelu primjenjivih ekonometrijskih analiza koje se bave problemima ekonomskog razvoja i lokalne ekonomske politike. Oni su neizbježni alati za analizu u međunarodnoj razmjeni i državnom planiranju, previranja na tržištu nafte, a ujedno su $i$ korišteni $u$ analizama porezne reforme, distribuciji blagostanja, te u zadnje vrijeme čak $i$ utjecaja globalnog zagrijavanja. Iz toga vidimo da je vrlo raširena primjena CGE modela. $U$ nekoliko posljednjih godina, napredak u specifikaciji modela, dostupnosti podataka i računalnoj tehnologiji je povećao isplativost $i$ smanjio troškove analiza koje su se temeljile na CGE modelima, što je postavilo preduvjete za sve masovniju i rašireniju upotrebu samih modela. Iako su se CGE modeli najčešće upotrebljavali kod analiza za zemlje u razvoju, osnovni okvir $i$ obilježja modela se mogu primjenjivati i korišteni su od svjetske razine do razine pojedine države, regije, sela ili čak pojedinog kućanstva.

Ključne riječi: CGE model, Općea ravnoteža, Hrvatsko Gospodarstvo. 